\title{
Quality of websites for gamete donation
}

\section{Websites de qualidade na doação de gametas}

\section{Sitios web de calidad en la donación de gametos}

\author{
Inês Baía ${ }^{1,2, a}$ \\ ines.baia@ispup.up.pt | https://orcid.org/oooo-0002-8621-6288 \\ Catarina Samorinha ${ }^{1, b}$ \\ catarina.samorinha@ispup.up.pt | http://orcid.org/oooo-0002-6662-0347 \\ Cláudia de Freitas ${ }^{1,3, c}$ \\ claudia.defreitas@ispup.up.pt | http://orcid.org/o0o0-0002-1828-8642
}

Helena Machado ${ }^{4, d}$

hmachado@ics.uminho.pt | http://orcid.org/oooo-0001-8554-7619

Isabel Sousa Pereira ${ }^{5, e}$

isabelsousapereira.pma@chporto.min-saude.pt | https://orcid.org/oooo-0002-8815-6602

Susana Silva $a^{1,2, f}$

susilva@ispup.up.pt | http://orcid.org/oooo-0002-1335-8648

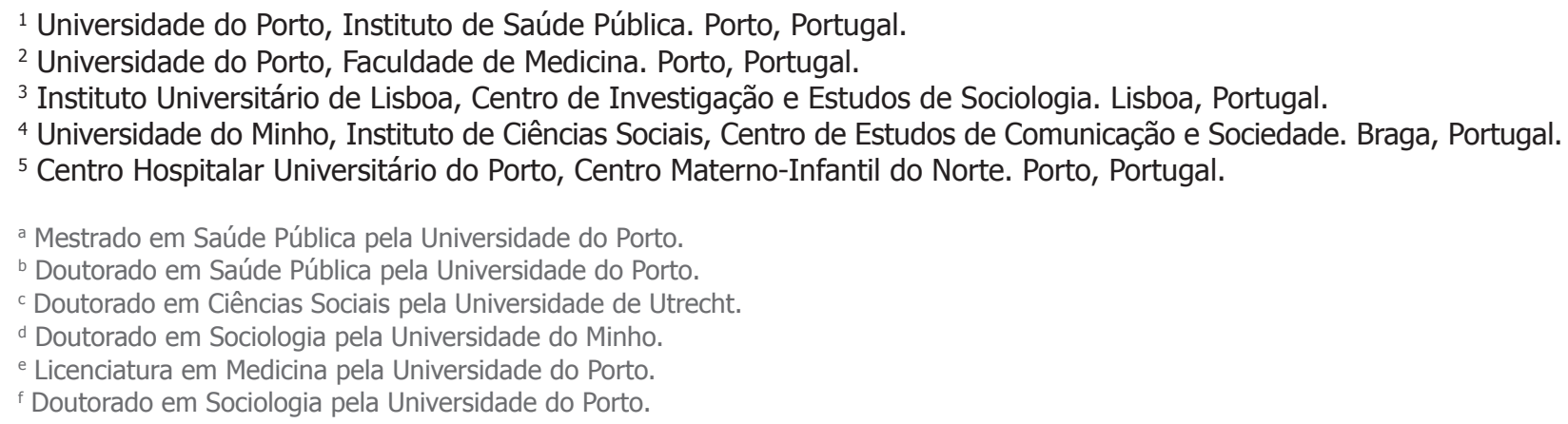

\begin{abstract}
This study aims to assess the quality of online health information about gamete donation based on a quantitative analysis of websites from fertility-clinics in Portugal. All websites providing information about gamete donation were comprehensively screened in June 2017. The reliability and usability of 43 webpages were assessed through the Website Information Evaluation Instrument from the Office of Disease Prevention and Health Promotion (ODPHP). None of the webpages met the purpose, content development, and updating criteria set by the ODPHP. Several shortcomings were observed: limited accessibility for users with disabilities, lack of simplified user experiences and easy search functionality, and lack of users' interaction with content. The quality of online information on gamete donation in fertility-clinics' websites requires improvement to become user-friendly. The development of specific guidelines and periodic evaluations of these websites using sensitive instruments, merging quantitative and qualitative assessments, is required to guarantee the quality of information that aims to improve reproductive health literacy through people-centered communication.
\end{abstract}

Keywords: Donor conception; Quality assurance, Health care; Patient education; Internet; Consumer health information. 


\section{Resumo}

Este estudo pretende avaliar a qualidade da informação online sobre doação de gametas em sites de clínicas de fertilidade em Portugal. Todos os sites com informação sobre doação de gametas foram escrutinados em junho de 2017. A confiabilidade e usabilidade de 43 páginas web foram avaliadas usando o instrumento Website Information Evaluation do Office of Disease Prevention and Health Promotion. Nenhuma página cumpriu os critérios de propósito, desenvolvimento e atualização de conteúdo. Encontraram-se várias lacunas na usabilidade: acessibilidade limitada para usuários com incapacidade, falta de clareza e de simplicidade de utilização, e impossibilidade de interagir com os conteúdos. Importa melhorar a qualidade da informação online sobre doação de gametas em clínicas de fertilidade, tornando-a mais amigável para o usuário. É necessário desenvolver guias específicos e avaliar periodicamente estes sites, usando instrumentos sensíveis que contemplem análises quantitativas e qualitativas, garantindo a sua qualidade para promover literacia em saúde reprodutiva através da comunicação centrada nas pessoas.

Palavras-chave: Concepção de doadores; Garantia da qualidade dos cuidados de saúde; Educação de pacientes; Internet; Informação de saúde ao consumidor.

\section{Resumen}

Este estudio evaluó la calidad de la información sobre la donación de gametos en sitios web de clínicas-defertilidad. Todos los sitios web de clínicas en Portugal fueron examinados (junio 2017). La confiabilidad y usabilidad de 43 páginas web fueron evaluadas con el Website Information Evaluation do Office of Disease Prevention and Health Promotion. Ninguna de las páginas cumplió con los criterios de propósito, desarrollo de contenido y actualización. Se observaron deficiencias: accesibilidad limitada para los usuarios con discapacidades, falta de una experiencia del usuario simplificada y baja funcionalidad de búsqueda fácil, y falta de interacción de los usuarios con el contenido. Importa mejorar la calidad de la información online sobre la donación de gametos en clínicas de fertilidad, para convertirse en fácil de usar. Es necesario el desarrollo de guías específicas y evaluaciones periódicas de los sitios web, utilizando instrumentos sensibles que combinen evaluaciones cuantitativas y cualitativas, promoviendo la alfabetización en salud reproductiva.

Palabras-clave: Concepción de donantes; Garantía de la calidad de atención de salud; Educación del paciente; Internet; Información de salud al consumidor.

INFORMAÇÕES DO ARTIGO

Contribuição dos autores: The study was designed by Silva S. Baía I wrote the first draft of the manuscript. Baía I, Samorinha C, and Silva S designed the analysis strategy. Samorinha C and Baía I collected and analyzed the data. All authors gave substantial contribution to the interpretation of data, critical discussion, revision of the manuscript, and approved its final version. All authors agreed to be accountable for all aspects of the work in ensuring that questions related to the accuracy or integrity of any part of the work are appropriately investigated and resolved.

Declaração de conflito de interesses: Authors declare that they have no conflict of interest to disclose.

Fontes de financiamento: This study was co-funded by national funding from the Foundation for Science and Technology - FCT (Portuguese Ministry of Science, Technology, and Higher Education), the Operational Programmes Competitiveness and Internationalization (COMPETE 2020) and Human Capital (POCH), Portugal 2020, and the European Union, through the European Regional Development Fund and the European Social Fund, under the Unidade de Investigação em Epidemiologia - Instituto de Saúde Pública da Universidade do Porto (EPIUnit) (POCI-01-0145-FEDER-006862; Ref. FCT UID/DTP/04750/2013), the project POCI-01-0145-FEDER-016762; Ref. FCT PTDC/IVC-ESCT/6294/2014, the Ph.D. grant SFRH/BD/111686/2015 (IB), the contract DL57/2016/CP1336/CT0001 (CF), and the FCT Investigator contract IF/01674/2015 (SS).

Considerações éticas: Not applicable.

Agradecimentos/Contribuições adicionais: The authors would like to thank the research team of the ENGAgED project, and colleagues from the Department of Health and Society from the Institute of Public Health, University of Porto, for all the relevant comments and suggestions to this work.

Histórico do artigo: submetido: 07 maio 2018 | aceito: 15 maio 2019 | publicado: 28 jun. 2019.

Apresentação anterior: This study was presented in the following scientific meetings: $5^{\circ}$ Congresso Ibero-Americano em Investigação Qualitativa; V Congresso Nacional de Saúde Pública; $7^{\text {th }}$ Conference of the European Survey Research Association and $2^{\text {nd }}$ European Congress of Qualitative Inquiry.

Licença CC BY-NC atribuição não comercial. Com essa licença é permitido acessar, baixar (download), copiar, imprimir, compartilhar, reutilizar e distribuir os artigos, desde que para uso não comercial e com a citação da fonte, conferindo os devidos créditos de autoria e menção à Reciis. Nesses casos, nenhuma permissão é necessária por parte dos autores ou dos editores. 


\section{Introduction}

Websites of in vitro fertilization (IVF) clinics are privileged vehicles for search and provision of fertilityrelated consumer health information to patients ${ }^{1,2}$, gamete donors ${ }^{3}$, and the general public ${ }^{4}$. These sites are also important sources of psychosocial support for patients, namely through internet forums ${ }^{2}$. They are also used as marketing tools, assisting clinics in advertising, recruiting, and matching donors to recipients in need of such services ${ }^{3.5}$. They may contribute to foster awareness and education about the causes of infertility and their treatments, benefits, and risks of gamete donation, and regulatory frameworks ${ }^{6,7}$. Thus, websites of IVF-clinics constitute major opportunity to foster reproductive health literacy and promote peoplecentered communication ${ }^{8}$ by providing clear, accurate, understandable, and up-to-date information ${ }^{7,9}$.

Responding to individuals' preferences, needs, and values is a central goal of integrated people-centered healthcare services ${ }^{10,11}$. To achieve this goal, it is necessary to promote individuals' health literacy ${ }^{12}$ and improve people-centered communication ${ }^{13,14}$. This may require the provision of and access to inclusive and equitative quality health education for all individuals ${ }^{15}$. One way to expand access to health education is investing in the delivery of online health information. Increasing access to online health information for patients and the general public has the potential to not only help improve health literacy but also empower them to undertake a more active role in decisions regarding their own health ${ }^{16-18}$. Guaranteeing the quality and credibility of health information websites is, thus, crucial to assure that the decisions made produce the best possible outcome for all parties involved ${ }^{17,18}$.

The importance of ensuring transparency, trustworthiness, privacy, accountability, reliability and accuracy of health information made available online to the public was recently reinforced by the World Health Organization ${ }^{19}$, the European Group on Ethics in Science and New Technologies ${ }^{7}$, and the American Society for Reproductive Medicine ${ }^{20}$, calling for the evaluation of health information made available online to citizens. Quality websites contribute to patient participation by increasing their confidence, autonomy, and self-determination ${ }^{21}$, enhancing patient and clinician communication ${ }^{22}$, and helping gamete donors and recipients to make informed decisions ${ }^{23}$. Quality websites are also particularly relevant in the search for cross-border reproductive care ${ }^{24}$ and transnational flow of gametes ${ }^{25}$. Conversely, poor-quality websites, which are difficult to use and are not reliable, can preclude adequate accessibility and understanding of information from users ${ }^{26}$.

Despite the consensual recognition of the need for quality websites, no empirical studies assessed the quality of information about gamete donation delivered by IVF-clinics websites. This study aimed to assess the quality of online health information about gamete donation based on a quantitative assessment of websites from IVF-clinics in Portugal.

\section{Methods}

On June 2017, the webpage of the Portuguese National Council for Assisted Reproductive Technologies was searched to identify all IVF-clinics providing treatments with gamete donation in Portugal ${ }^{27}$. From the 18 identified IVF-clinics, 13 out of the 15 private clinics provided online information about gamete donation, and the National Health Service provided information about the 3 public clinics. A total of 14 websites were comprehensively screened to select all webpages related to gamete donation. The final sample included 43 webpages (Chart 1). 
Chart 1 - Webpages included in the analysis

\begin{tabular}{|c|c|}
\hline Website & Webpages \\
\hline \multirow{8}{*}{ www.avaclinic.pt } & www.avaclinic.pt/doacao \\
\hline & www.avaclinic.pt/doacao-feminina \\
\hline & www.avaclinic.pt/doacao-masculina \\
\hline & www.avaclinic.pt/doacao/a-dadora-de-ovulos \\
\hline & www.avaclinic.pt/doacao/a-receptora \\
\hline & www.avaclinic.pt/doacao/a-dadora-na-ava-clinic \\
\hline & www.avaclinic.pt/tratamentos/casais-mulheres-sem-parceiro \\
\hline & www.avaclinic.pt/tratamentos/fertilizacao-reciproca-metodo-ropa \\
\hline www.british-hospital.pt & $\begin{array}{l}\text { www.british-hospital.pt/pt/especialidades/detalhe/pagina/especialidades-centro-de- } \\
\text { medicina-da-reproducao }\end{array}$ \\
\hline www.ceie.pt & www.ceie.pt/ceie/doacao \\
\hline \multirow{2}{*}{ www.cemeare.pt } & www.cemeare.pt/tratamentos-infertilidade-clinica-lisboa.php \\
\hline & www.cemeare.pt/infertilidade-conjugal-doar-ovulos-ovocitos-clinica-lisboa.php \\
\hline \multirow{5}{*}{ www.ceti-porto.com } & www.ceti-porto.com/quero-doar-c13qx \\
\hline & www.ceti-porto.com/doacao-de-ovocitos \\
\hline & www.ceti-porto.com/doacao-de-espermatozoides \\
\hline & www.ceti-porto.com/quero-doar-cw0u \\
\hline & www.ceti-porto.com/perguntas-frequentes \\
\hline \multirow{2}{*}{ www.cgrabarros.pt } & www.cgrabarros.pt/doacao.htm \\
\hline & www.criarfamilias.com.pt \\
\hline \multirow[t]{2}{*}{ www.clinicafertimed.org } & $\begin{array}{l}\text { www.clinicafertimed.org/inseminacao-artificial-tratamento-da-esterilidade-e-da- } \\
\text { infertilidade }\end{array}$ \\
\hline & www.clinicafertimed.org/fertilizacao-vitro-tratamento-da-esterilidade-e-da-infertilidade \\
\hline www.clinimer.com & www.clinimer.com/tratamentos \\
\hline www.ferticare.pt & www.ferticare.pt/servicos \\
\hline \multirow{5}{*}{ www.ferticentro.pt } & www.ferticentro.pt/doarovulos \\
\hline & www.ferticentro.pt/doaresperma \\
\hline & www.ferticentro.pt/pt/tratamentos/doacao_ovulos \\
\hline & www.ferticentro.pt/pt/tratamentos/doacao_esperma \\
\hline & www.ferticentro.pt/pt/tratamentos/doacao_esperma1 \\
\hline \multirow{9}{*}{ www.ivi.pt } & www.ivi.pt/tratamentos-reproducao-assistida/doacao-de-semen \\
\hline & www.ivi.pt/tratamentos-reproducao-assistida/doacao-de-ovocitos \\
\hline & www.ividoa.pt \\
\hline & www.ividoa.pt/porque-ser-dadora-ovulos \\
\hline & www.ividoa.pt/doar-e-recompensado \\
\hline & www.ividoa.pt/o-processo-doacao-de-ovulos \\
\hline & www.ividoa.pt/nosotras \\
\hline & www.ividoa.pt/blog \\
\hline & www.ividoa.pt/faqs \\
\hline \multirow{4}{*}{ www.maloclinic-ginemed.com } & www.maloclinic-ginemed.com/reproducao-assistida/dadores \\
\hline & www.maloclinic-ginemed.com/reproducao-assistida/doacao-de-ovulos \\
\hline & www.maloclinic-ginemed.com/reproducao-assistida/dupla-doacao \\
\hline & www.maloclinic-ginemed.com/reproducao-assistida/resultados/doacao-ovulos \\
\hline www.meka.pt & www.meka.pt/doacao_ovulos \\
\hline www.sns.gov.pt & www.sns.gov.pt/cidadao/banco-publico-de-gametas-2 \\
\hline
\end{tabular}

Source: Search data (2017). 
The Office of Disease Prevention and Health Promotion Website Information Evaluation Instrument was used to assess quality in the selected webpages. This instrument was developed by experts in health communication and technology in the framework of Healthy People $2020^{28}$, aiming to improve the quality and accessibility of online health information. It provides a standardized and validated tool to assess the following two formal components of quality in websites and is the most complete tool compared to others ${ }^{29,30}$ : a) reliability, which evaluates accuracy and credibility of the website content as well as transparency in its purpose and ownership; and b) usability, referring to site assessment, content design, and information architecture, which affect users' ability to access, understand, and obtain online information. Reliability includes six criteria that measure 15 items: identity (name and address of the entity responsible for the website and funding sources); purpose (website mission, uses and limitations, and association with commercial products); content development (advertising, editorial policies, and content authorship); privacy (privacy policies description); user feedback (feedback forms); and content updating (date of content creation and revision). Each of these items is classified as present or absent ("Yes/No" answers), and each criterion is fulfilled only if all its items are present. Usability comprises 19 principles across 59 task-based measures ranked in a 4-point scale from 1 [task failure] to 4 [minimal problems] and based on the level of difficulty performing the task when assessing the webpage to search for information. An average rating score is calculated for each usability principle. A score of $\geq 3.5$ is required to comply with each principle $^{28}$. In the case of reliability, two researchers assessed all the webpages independently, and a third researcher sorted out ambiguities by assessing the webpage based on the same criteria. The total consensus was reached for the reliability criteria. The rating score for each usability principle was calculated based on the arithmetic mean of the scores given by two researchers. The fact that usability is scored on a 4-point scale increases the difficulty in reaching interrater reliability (IRR) in this component ${ }^{28}$. To ensure IRR, both reviewers assessed the same websites during an initial training process, calculated the IRR for each assessment, identified discrepancies, and resolved them between the two reviewers until IRR scores met benchmark kappa scores. A good intraclass coefficient $(\mathrm{ICC}=0.62)$ was reached for the usability evaluation, which met the proposed benchmark score ${ }^{28}$.

A descriptive analysis was performed to present the proportion of webpages depicting reliability criteria and usability principles. The corresponding 95\% confidence intervals (95\% CI) are presented. The statistical analysis was conducted using IBM SPSS Statistics, version 23.o.

\section{Results}

The reliability of the assessed webpages was poor. None of them met the criteria of purpose, content development and content updating, and only one met the identity requirement. There was a lack of identification of uses and limitations of these webpages and failure to describe editorial policies, authorship, dates, and responsibility of content creation and updating [Chart 2]. All the webpages provided the possibility of user feedback (e.g., feedback form, email address). However, only 30.2\% (95\% CI, 17.2-46.1) met the privacy criteria (i.e., describing confidentiality policies and explaining how users' personal data is protected). 
Chart 2 - Count and proportion of webpages $(N=43)$ presenting fulfilled reliability criteria

\begin{tabular}{|c|c|c|}
\hline Reliability criteria & Count & $\%(95 \% \mathrm{CI})$ \\
\hline Identity & 1 & $2.3(0.0-12.3)$ \\
\hline Name & 43 & 100.0 (n.a) \\
\hline Street address & 42 & $97.6(87.7-99.9)$ \\
\hline Funding sources & 1 & $2.3(0.0-12.3)$ \\
\hline Purpose & 0 & 0.0 (n.a) \\
\hline Purpose or mission & 39 & $90.7(77.9-97.4)$ \\
\hline Uses and limitations & 23 & $53.5(37.7-68.8)$ \\
\hline Association with commercial products & 0 & 0.0 (n.a) \\
\hline Content Development & 0 & 0.0 (n.a) \\
\hline Identification of advertising content & 0 & 0.0 (n.a) \\
\hline Description of editorial policy & 2 & $4.7(0.6-15.8)$ \\
\hline Authorship & 17 & $39.5(25.0-55.6)$ \\
\hline Privacy & 13 & $30.2(17.2-46.1)$ \\
\hline Privacy policy & 13 & $30.2(17.2-46.1)$ \\
\hline Description of protection of personal information & 13 & $30.2(17.2-46.1)$ \\
\hline User Feedback & 43 & 100.0 (n.a) \\
\hline Feedback mechanism & 43 & 100.0 (n.a) \\
\hline Content Updating & 0 & 0.0 (n.a) \\
\hline Display date created & 0 & 0.0 (n.a) \\
\hline Display date reviewed or updated & 0 & 0.0 (n.a) \\
\hline
\end{tabular}

Source: Search data (2017).

* n.a - not applicable.

Concerning usability, $41.9 \%$ of the webpages complied with less than 10 out of 19 principles (data not shown). Major shortcomings were observed regarding accessibility for users with disabilities by providing a simplified user experience (print options, feedback mechanisms for users, and accessibility of the homepage) in the absence of an easy search functionality and options for users' interaction with content. These issues prevented users the ability to input information and choose preferences or share content with others; none of the evaluated webpages complied with these principles. Only one webpage presented a clear visual hierarchy (2.3\% [95\% CI, 0.1-12.3]). The highest compliance was reached for the following principles [Chart 3]: the back button behaves predictably (97.7\% [95\% CI, 87.7-99.9]); easiness to read elements on the page (93.0\% [95\% CI, 80.9-98.5]); clearly labelled content categories (90.7\% [95\% CI, 77.9-97.4); and usage of user-friendly language minimizing jargon and technical terms (90.7\% [95\% CI, 77.9-97.4]). 


\begin{tabular}{|c|c|c|}
\hline Usability principles & Count & $\%(95 \% \mathrm{CI})$ \\
\hline \multicolumn{3}{|l|}{ Site Design } \\
\hline 1. Uses conventional interaction elements & 12 & $36.4(20.4-54.9)$ \\
\hline 2. Makes it obvious what is clickable and what is not & 34 & $79.1(64.0-90.0)$ \\
\hline 3. Minimizes vertical scrolling & 30 & $69.8(53.9-82.8)$ \\
\hline 4. Ensures that the back button behaves predictably & 42 & $97.7(87.7-99.9)$ \\
\hline 5. Provides clear feedback signals for actions & 27 & $62.8(46.7-77.0)$ \\
\hline $\begin{array}{l}\text { 6. Ensures site is accessible for users with disabilities and uses } \\
\text { elements of } 508 \text { compliance }\end{array}$ & 0 & $0.0($ n.a) \\
\hline 7. Provides a simplified user experience & 0 & 0.0 (n.a) \\
\hline 8. Incorporates multimedia & 7 & $16.3(6.8-30.7)$ \\
\hline 9. Offers a functional home page & 36 & $83.7(69.3-93.2)$ \\
\hline \multicolumn{3}{|l|}{ Information architecture } \\
\hline 10. Presents a clear visual hierarchy & 1 & $2.3(0.1-12.3)$ \\
\hline 11. Provides easy search functionality & 0 & 0.0 (n.a) \\
\hline 12. Clearly labels content categories & 39 & $90.7(77.9-97.4)$ \\
\hline 13. Makes pages easy to skim or scan & 23 & $53.5(37.7-68.8)$ \\
\hline 14. Makes elements on the page easy to read & 40 & $93.0(80.9-98.5)$ \\
\hline 15. Visually groups related topics & 35 & $81.4(66.6-91.6)$ \\
\hline 16. Makes sure text and background colours contrast & 31 & $72.1(56.3-84.7)$ \\
\hline \multicolumn{3}{|l|}{ Content design } \\
\hline 17. Focuses the writing on audience and purpose & 11 & $25.6(13.5-41.5)$ \\
\hline 18. Uses the users' language; minimizes jargon and technical terms & 39 & $90.7(77.9-97.4)$ \\
\hline 19. Allows for interaction with the content & 0 & 0.0 (n.a) \\
\hline
\end{tabular}

Source: Search data (2017).

*n.a - not applicable.

\section{Discussion}

The assessment of the quality of online health information on gamete donation provided by the websites of IVF-clinics located in Portugal reveals gaps regarding both reliability and usability. The promotion of transparency, trustworthiness, accountability, and accuracy requires the development and update of content, improved privacy practices and policies, identification of funding sources, and clarification of associations with commercial products ${ }^{5,7}$. Previous studies highlight patients' difficulties in evaluating the quality of online information about infertility mainly due to lack of identification of sources of information in websites ${ }^{31}$ and absence of a peer review process and editorial oversight of contents and updates ${ }^{32}$. 
This type of surveillance on sources of online health information is particularly relevant to ensure that the information provided is still accurate, understandable, and targeted for the users' needs and preferences ${ }^{33}$.

A lack of focus on the user is evidenced by the following aspects: lack of website's accessibility for users with disabilities and lack of a simplified user experience; scarce incorporation of multimedia without clear visual hierarchy; absence of easy search functionalities; and difficulties in users' interaction with content. The incorporation of multimedia patient education and consent tools can increase the accessibility and user-friendliness in websites ${ }^{31}$; this will make websites important mediums for fostering awareness and education in fertility ${ }^{6,7}$ while potentially decreasing the feeling that consent is a bureaucratic routine ${ }^{34}$ by grounding it in informed shared decision-making.

Furthermore, the results of this study draw attention to the need to disseminate guidelines aimed at promoting user-friendly websites. The traditional focus on service providers as the main agents responsible for the evaluation of the quality of online health information needs to be challenged by highlighting the coresponsibility of health institutions and policy-makers in the development of specific guidelines and periodic evaluations of websites that take into account the socioethical implications of gamete donation ${ }^{35}$. Quality gold-standard guidelines should be developed by a multidisciplinary team to guide those responsible for website development on the type of information and the way they should be provided ${ }^{31,32}$. The development of websites that are evaluated and certified by independent health authorities is, therefore highlighted 7 .

\section{Final considerations}

This study constitutes an exploratory first step in the assessment of the quality of online information on gamete donation. Based on websites of fertility clinics in Portugal, the study revealed that the quality of online information on gamete donation requires improvement to become user-friendly and assurance of the websites' usability and reliability. Based on quantitative indicators, these findings provide relevant information that can be used by fertility clinics in making improvements to their websites available to the public.

Considering the absence of standardized criteria for evaluating web-based health information on gamete donation, it is of utmost importance to develop these criteria to assess the quality and adequacy of content in these websites; similarly, these criteria are relevant to those already existing websites related to other health topics ${ }^{36}$. The development of tools that integrate quantitative and qualitative indicators, sensitive to gamete donation and including content analysis of websites, should be performed to improve reproductive health literacy through people-centered communication. Finally, evidence on the perspectives and needs of users regarding their experiences with websites is needed to promote people-centered models for the development of webpages related with gamete donation.

\section{References}

1. Talarczyk J, Hauke J, Poniewaz M, Serdynska-Szuster M, Pawelczyk L, Jedrzejczak P. Internet as a source of information about infertility among infertile patients. Ginekol Pol. 2012;83(4):250-4.

2. Van Hoof W, Provoost V, Pennings G. Reflections of dutch patients on IVF treatment in Belgium: a qualitative analysis of internet forums. Human Reprod. 2013;28(4):1013-22.

3. Keehn J, Holwell E, Abdul-Karim R, Chin LJ, Leu CS, Sauer MV, et al. Recruiting egg donors online: an analysis of in vitro fertilization clinic and agency websites' adherence to American Society for Reproductive Medicine guidelines. Fertil Steril. 2012;98(4):995-1000.

4. Hammarberg K, Zosel R, Comoy C, Robertson S, Holden C, Deeks M, et al. Fertility-related knowledge and information-seeking behaviour among people of reproductive age: a qualitative study. Hum Fertil (Camb). 2017;20:88-95.

5. Keehn J, Howell E, Sauer MV, Klitzman R. How Agencies Market Egg Donation on the Internet: A Qualitative Study. J Law Med Ethics. 2015;43(3):610-618. 
6. Hudson N, Culley L, Rapport F, Johnson M, Bharadwaj A. "Public" perceptions of gamete donation: a research review. Public Underst Sci. 2009;18(1):61-77.

7. European Group on Ethics in Science and New Technologies to the European Comission. Opinion on the ethical implications of new health technologies and citizen participation [Internet]. Luxembourg: The Group; 2016 [cited 2017 Jan 05]. Available from: https://bit.ly/2W2x9B8.

8. Diviani N, van den Putte B, Meppelink CS, van Weert JC. Exploring the role of health literacy in the evaluation of online health information: Insights from a mixed-methods study. Patient Educ Couns. 2016;99(6):1017-1025.

9. Committee on improving the quality of cancer care: addressing the challenges of an aging population; board on health care services; institute of medicine. Patient-centered communication and shared decision making. In: Levit L, Balogh E, Nass SJ, Ganz PA, et al., editors. Delivering high-quality cancer care: charting a new course for a system in crisis. Washington DC: National Academies Press; 2013. p. 91-152.

10. World Health Organization. Placing people and communities at the centre of health services. WHO global strategy on integrated people-centred health services 2016-2026. Geneva: The Organization; 2015.

11. Epstein RM, Street Jr RL. Patient-centered communication in cancer care: promoting healing and reducing suffering. Bethesda, MD: National Cancer Institute. National Institutes of Health; 2007. NIH number 07-6225.

12. Coleman C, Hudson S, Pederson B. Prioritized health literacy and clear communication practices for health care professionals. Health Lit Res Pract. 2017;1(3):e91-e99.

13. Institute of Medicine. Committee on Quality of Health Care in America. Crossing the quality chasm: a new health system for the 21st century. Washington DC: National Academies Press; 2001.

14. King A, Hoppe RB. "Best practice" for patient-centered communication: a narrative review. J Grad Med Educ. 2013;5(3):385-93.

15. United Nations. Transforming our world: The 2030 agenda for sustainable development [Internet]. New York: United Nations; 2015 [cited 2019 Apr 15]. Available from: https://bit.ly/2K2UbAo.

16. Diviani N, van den Putte B, Meppelink CS, van Weert JC. Exploring the role of health literacy in the evaluation of online health information: Insights from a mixed-methods study. Patient Educ Couns. 2016;99(6):1017-25.

17. Richards T, Coulter A, Wicks P. Time to deliver patient centred care. BMJ. 2015;10(350):h530.

18. Eysenbach G. Consumer health informatics. BMJ. 2000;320(7251):1713-16.

19. World Health Organization. The Health internet: governing principles for a .health top-level domain [Internet]. Geneva: The Organization; 2014 [cited 2017 Jan 05]. Available from: https://bit.ly/2I7oqDF.

20. Abusief ME, Hornstein MD, Jain T. Assessment of United States fertility clinic websites according to the American Society for Reproductive Medicine (ASRM)/Society for Assisted Reproductive Technology (SART) guidelines. Fertil Steril. 2007;87(1):88-92.

21. De Bronkhart D. From patient centred to people powered: autonomy on the rise. Brit Med J 2015;350:h148-150.

22. Kahlor L, Mackert M. Perceptions of infertility information and support sources among female patients who access the Internet. Fertil Steril. 2009;91(1):83-90.

23. Agree EM, King AC, Borzekowski DL, Castro CM, Wiley A. "It's got to be on this page": age and cognitive style in a study of online health information seeking. J Med Internet Res. 2015;17(3):e79.

24. Lunt N, Hardey M, Mannion R. Nip, tuck and click: medical tourism and the emergence of web-based health information. Open Med Inform J. 2010;4:1-11.

25. Gürtin ZB, Inhorn MC. Introduction: travelling for conception and the global assisted reproduction market. Reprod Biomed Online. 2011;23(5):535-7.

26. Office of Disease Prevention and Health Promotion Healthy People (ODPHP) HC/HIT objectives 8.1 and 8.2: National Quality Health Website Survey Research Report. Rockville: Office of the Assistant Secretary for Health, U.S. Department of Health and Human Services (HHS); 2015. 
27. Conselho Nacional de Procriação Medicamente Assistida (CNPMA). Relatório referente à atividade desenvolvida pelo CNPMA nos anos 2014 a 2015 (n. 3 do artigo 30. ${ }^{\circ}$ da Lei n. ${ }^{\circ}$ 32/2006, de 26 de julho) [Internet]. Lisboa: Conselho Nacional de Procriação Medicamente Assistida; 2016 [acesso 2017 jan. 05]. Disponível em: https://bit.ly/2HFQn6y.

28. Devine T, Broderick J, Harris LM, Hilfiker SW, Wu H. Making Quality Health Websites a National Public Health Priority: Toward Quality Standards. J Med Internet Res. 2016;18(8):1-11.

29. Charnock D, Shepperd S, Needham G, Gann R. DISCERN: an instrument for judging the quality of written consumer health information on treatment choices. J Epidemiol Community Health. 1999;53(2):105-11.

30. Health On the Net Code of Conduct (HONcode) [Internet]. The commitment to reliable health and medical information on the Internet. Switzerland: Health On the Net Code of Conduct; 2014 [cited 2017 Jan 04]. Available from: http://www.hon.ch/HONcode/.

31. Robins S, Barr HJ, Idelson R, Lambert S, Zelkowitz P. Online health information regarding male infertility: an evaluation of readability, suitability, and quality. Interact J Med Res. 2016;5(4):e25.

32. Marriott JV, Stec $P$, El-Toukhy $T$, Khalaf $Y$, Braude $P$, Coomarasamy A. Infertility information on the World Wide Web: a cross-sectional survey of quality of infertility information on the internet in the UK. Human Reprod. 2008;23(7):1520-25.

33. Beaunoyer E, Arsenault M, Lomanowska AM, Guitton MJ. Understanding online health information: Evaluation, tools and strategies. Patient Educ Couns. 2017;100(2):183-9.

34. Madeira JL, Coyne K, Jaeger AS, Parry JP, Lindheim SR. Inform and consent: more than just "sign here". Fertil Steril. 2017;108(1):40-1.

35. Silva SP, Freitas C, Baía I, Samorinha C, Machado H, Silva S. Doação de gametas: questões sociais e éticas (não) respondidas em Portugal. Cad. Saúde Pública. 2019;35(2):e00122918.

36. Ferreira D, Carreira H, Silva S, Lunet N. Assessment of the contents related to screening on Portuguese language websites providing information on breast and prostate cancer. Cad. Saúde Pública. 2013;29(11):2163-76. 